\title{
Effect of Phosphorus Level and Some Growth Regulators on Productivity of Faba Bean (Vicia Faba L.)
}

\author{
K.F. Fouda
}

Soil Sci. Dept., Fac. of Agric., Mansoura Univ., Egypt

\begin{abstract}
A FIELD experiment was conducted on Faculty of Agric. El-Mansoura Univ. during season of 2014-2015 to investigate the effect of phosphorus fertilizer levels with foliar application of (gibberellin, humic acid and cyitokinen) on faba bean (var.sakha 4).

Sixteen treatments were arranged in a split-block design, which were the simple possible combination between four levels of phosphorus fertilizer i.e. 0,50, 75 and 100\% P2O5/fed (recommended dose) for faba bean plant as main plots and four treatments of growth regulators (without, gibberellin (GA3), humic acid (HA) and cyitokinen (CK)), each treatment was replicated three times.
\end{abstract}

The results showed that; soil application of phosphorus fertilizer levels significantly increased the average values of plant growth parameter ,yield and its components and chemical constituents of faba bean plant as well as available N,P and K of soil after harvesting stage . The highest values recorded with using $75 \%$ from recommended dose P-fertilizers. With in the growth regulators investigated; a superiority effect was happened on all parameters under study for the plants treated with humic acid following with GA3 and lastly CK as compared to control treatment. Generaly, the most suitable treatment, which realizing the highest yield of faba bean seeds was connected with the treatment of $75 \%$ ( R.D) + humic acid .

\section{Introduction}

Legume plants play a key role in sustainable agriculture and present economic and environmental benefits due to their important capacity to fix atmospheric nitrogen in the root nodules in symbiotic relationship with rhizobia. Symbiotic rhizobia can increase yields, accelerate flowering/fruit ripening and contribute to the improvement of the soil nitrogen balance for the benefit of legumes and associated species (Jia and Gray, 2008).

Faba bean (Vicia faba L.,) is considered one of the most important legumes in Egypt. It has become one of the strategic crops due to its income to the farmers. Also, Faba bean is popular legume food and used in worldwide as an important source of protein for human and animal nutrition (Cazzato et al., 2012). It's important for soil fertility, human nutrition as a good source of vegetarian protein animal feeding and industry purposes (Sharaan et al., 2004).

Phosphorus is a major nutrient, especially for legumes. It is considered the second essential nutrient element for both plants and microorganisms. In spite of the considerable addition of phosphorus to soil, the amount of available for plant is usually low. Phosphate dissolving bacteria and soil microorganisms can play an important role in improving plant growth. Many researchers showed positive effect of phosphorus fertilization on faba bean. Faba bean may require $P$ fertilizer in the range of 20 to 30 $\mathrm{kg}$ P ha-1 (FAO, 2000). Significant increases were achieved in faba bean yield and its attributes by increasing phosphorus fertilization rate up to 45$46.5 \mathrm{~kg}$ P2 O5 /fed (El-Habbasha et al., 2007). 
Gibberellins,a group of diterpenoid plant hormones, have an important role in regulation of diverse developmental processes in plants such as seed germination, cell and organ elongation as well as flowering and have wide applications in modern agriculture (Taiz and Zeiger, 2010).

Humic materials are the final product of decomposition of each organic matter in specific conditions by a special microorganism. Some of the characteristics of humic acid are: it improves soil structure; it contributes in rooting; it increases plant growth promoting bacteria in soil and finally reduces toxicity of fertilizers and extra nutrients in soil (Samavat, 2007).

Cytokinens are known to stimulate or inhibit a great number of physiological processes. however, great variability can be observed in reported results. These dissimilar results primarily occur because of differences between concentrations utilized and differences in the physiological stages at which these products are applied. CK can be utilized in a variety of applications, from the treatment of seeds to applications during flowering, and the same is true about GA ( Maske et al., 1997).

This study was conducted to determine the effect of P- fertilizer levels on chemical composition and quality of faba bean plants under foliar application of (gibberellin, humic acid and cyitokinen) on faba bean plant.

\section{Materials and Methods}

A field experiment was conducted using faba bean plant (Vicia faba L.) sakha 4 variety during 2014-2015 season at the Experimental Farm of the Faculty of Agric. El-Mansoura Univ., to study the effect of combined use of phosphorus fertilizer levels under foliar application (gibberellin, humic acid and cyitokinen) on faba bean plant.

Sixteen treatments were arranged in a splitblock design, which were the simple possible combination between four levels of phosphorus fertilizer, i.e. 0, 50, 75 and 100\% $\mathrm{P} 2 \mathrm{O} 5 /$ fed from the recommended dose by (MASR) for faba bean plant as main plots and four treatments of growth regulators (without, gibberellin (GA3), humic acid (HA) and cyitokinen (CK)). Other agricultural practices were done according to the recommended for faba bean plant by the ministry of agriculture.
TABLE 1. Physical and chemical properties of the used soil during experiment

\begin{tabular}{|c|c|c|}
\hline \multicolumn{3}{|c|}{ Soil characters } \\
\hline \multirow{5}{*}{$\begin{array}{l}\text { Particle size } \\
\text { distribution } \\
(\%)\end{array}$} & Coarse sand & 2.98 \\
\hline & Fine sand & 26.77 \\
\hline & Silt & 37.84 \\
\hline & Clay & 32.41 \\
\hline & Texture class & Sandy clay loam \\
\hline \multicolumn{2}{|c|}{ E.C, dS.m ${ }^{-1}(1: 5)$} & 1.03 \\
\hline \multicolumn{2}{|c|}{$\mathrm{pH}(1: 2.5)$} & 7.88 \\
\hline \multicolumn{2}{|c|}{ S.P. $\%$} & 57.8 \\
\hline \multicolumn{2}{|c|}{ O.M. \% } & 1.96 \\
\hline \multicolumn{2}{|c|}{ T. $\mathrm{CaCO}_{3} \%$} & 3.75 \\
\hline \multirow{3}{*}{$\begin{array}{l}\text { Available } \\
(\mathrm{mg} / \mathrm{kg})\end{array}$} & $\mathrm{N}$ & 47.9 \\
\hline & $\mathrm{P}$ & 4.97 \\
\hline & $\mathrm{K}$ & 219.4 \\
\hline
\end{tabular}

Some physical and chemical properties of the experimental soil before planting are shown in Table 1. At flowering stage, representative sample from the plants of each treatment were collected to determine chlorophyll content, fresh and dry weigh g.plant-1 as well as $\mathrm{N}, \mathrm{P}$ and $\mathrm{K} \%$, in faba bean leaves. Also, number of flowers were taken and fruit setting $\%$ was calculated according to the quality of fruit setting $\%=$ no. of pods.plant $t^{-1} /$ no. of flowers.plant ${ }^{-1} * 100$.

At harvesting stages; pods of each plant were harvested at full maturity stage (120 days after sowing), counted and weight to determine the yield and its components (seed index, number of pods.plant ${ }^{-1}$, weight of pods. plant ${ }^{-1}$ and total yield kg.fed ${ }^{-1}$ ).

Samples of faba bean seeds were taken from each treatment, To determine $\mathrm{N}, \mathrm{P}$ and $\mathrm{K} \%$.and quality parameters of faba bean seeds (C.protein, T.carbohydrate \%, C. fiber \% and Ash \%). After harvesting, representative sample from the experimental soil was taken to determine available N.P and K .

\section{Soil analysis}

- The electrical conductivity values of the 1: 5 soil paste extracts were measured by EC, $\mathrm{pH}$ value, $\mathrm{CaCo} 3$ and organic matter contents were determined according to Sahlemedhin and Taye (2000).

- $\quad$ Particle size distribution, available N, P and 
$\mathrm{K}$ in the soil were determined according to the methods of Haluschak (2006) and Reeuwijk, (2002).

\section{Chemical composition and quality of fruits}

- Total N, P and K (\%) was determined according to the methods described by Mertens (2005 a \& b) and Agrilasa (2002), respectively.

- Chlorophyll content was estimated as the method described by Gavrilenko and Zigalova (2003).

- NO3-N (mg $\backslash \mathrm{kg})$, Vitamin C (mg $\backslash 100 \mathrm{~g})$, Acidity \%, Lycobin, and T.S.S.\% as well as total cabohydrates \% were determined according to Singh (1988), (A.O.A.C,2006), Wu (2002), and Ranganna (2001), respectively.

All data were statistically analyzed according to the technique of analysis variance (ANOVA) and the least significant difference (L.S.D) method was used to compare the deference between the means of treatment values to the methods described by Gomez and Gomez (1984). All statistical analyses were performed using analysis of variance technique by means of CoSTATE Computer Software.

\section{Results and Discussion}

\section{Plant growth parameters}

Presented data in Table 2 show the effect of treating faba bean plants with different rats of phosphorus fertilization (50, 75 and 100\% R.D) in comparison with the control treatment on vegetative growth characters of faba bean plants expressed as fresh and dry weight per plant. It is obvious from the presented data that increasing phosphorus fertilization up to $75 \%$ increased significantly fresh and dry weight comparing with the untreated plant.

An alleviation effect happened due to addition of P-fertilization at the rates of this study. This could be attributed to the fact that phosphorus is required in large quantities in shoot tips where metabolism is high and cell division is rapid (Ndakidemi and Dakora, 2007). Thus, an indication that the faba bean plant utilized the phosphorus fertilizer applied judiciously in growth and development processes. The beneficial role played by phosphorus for the growth of the root system epidermal osmotic adjustment and fundamental role in the number of enzimatic reaction that depends on phosphorelation. Abdalsalam and Al-Shebani (2010) found that phosphorus application enhanced all growth and yield parameters for mungbean.

Results in Table 2 illustrated the effect of foliar spray with some natural materials, i.e. gibberellin, humic acid and cytokinen in comparison with untreated plants on vegetative growth characters of faba bean plants.

It is clear from the data that spraying faba bean plants with all tested materials enhanced significantly fresh and dry weight by spraying with humic acid which did not reach to $5 \%$ level of significant. The most favorable treatments in this respect were humic acid followed by gibberellin then cytokinen.

The increase in vegetative growth characters by spraying humic acid on plant growth could be referred to its acting as source of plant growth hormones (Nardi et al., 1999). Afifi et al. (2010) indicated that foliar application with humic acid improved nutrient status and promoted growth and yield components of faba bean plants.

Data revealed that the foliar application of humic acid increased fresh and dry weight under different levels of $\mathrm{P}_{2} \mathrm{O}_{5}$. The highest significantly levels of fresh and dry weight of faba bean plants 11.43 and 15.47 were obtained when $75 \% \mathrm{P}_{2} \mathrm{O}_{5}$ and humic acid used. Mesut (2010) pointed out that humic acid and phosphorus applications increased the growth and yield parameters of pepper seedling.

\section{Data of flowering}

Table 3 showed the effect of $\mathrm{P}$ fertilizaers, foliar application (gibberellin, humic acid and cyitokinen and its interaction on number of flowers/plant, number of pods/plant, as well as calculated percentage of fruit setting.

It could be noticed that; soil addition of P-fertilizer at rates of 50, 75 and $100 \% \mathrm{P}_{2} \mathrm{O}_{5}$ significantly increased the mean values of number of pods/plant and number of flowers/plant, and fruit setting $\%$. The highest mean values of mentioned parameters reveled with increasing $\mathrm{P}$ up to $75 \%$ and decreased with high levels $100 \%$ comparing with the control. As a result of a beneficial effect 
of phosphorus on stimulating the development of root hairs which absorb more nutrients from the soil solution. The important role played by phosphorus in enzymatic reactions is well known too. Obtained results are confirmed with those reported by Ahmed and El-Abagy (2007) studied the effect of mineral phosphorus fertilizer on the growth, productivity and nutritional value of faba bean. They observed that faba bean cultivars significantly differed in number of pods, seeds/ plant, weight of pods/plant, seed and straw yield per plant and/or per fed, biological yield/ fed, protein \% per seeds as well as protein yield/ fed. The increment in yield and its components regarding supplied faba bean plants with $46.5 \mathrm{Kg}$ P2O5/fed. may be attributed to the physiological role of $\mathrm{P}$ on the meristematic activity of plant tissues and consequently increasing plant growth, also, its function as a part of enzyme system having a vital role of the synthesis of other foods from carbohydrate.

TABLE 2. Effect of different phosphorus level and foliar application (gibberellin, humic acid and cyitokinen) fresh and dry weight for faba bean

\begin{tabular}{|c|c|c|c|}
\hline \multicolumn{2}{|c|}{ Treatments } & Fresh weight (g/plant) & Dry weight (g/plant) \\
\hline \multicolumn{4}{|c|}{ P fertilization } \\
\hline \multicolumn{2}{|c|}{ without } & 92.32 & 12.28 \\
\hline \multicolumn{2}{|c|}{$50 \%$} & 97.49 & 13.27 \\
\hline \multicolumn{2}{|c|}{$75 \%$} & 106.33 & 14.66 \\
\hline \multicolumn{2}{|c|}{$100 \%$} & 102.93 & 14.17 \\
\hline \multicolumn{2}{|c|}{ LSD $_{\text {at } 5 \%}$} & 1.05 & 0.09 \\
\hline \multicolumn{4}{|c|}{ Growth Regulator } \\
\hline \multicolumn{2}{|c|}{ Without } & 93.32 & 12.42 \\
\hline \multicolumn{2}{|c|}{ GA3 } & 101.88 & 13.99 \\
\hline \multicolumn{2}{|c|}{ HA } & 103.49 & 14.23 \\
\hline \multicolumn{2}{|c|}{$\mathbf{C K}$} & 100.38 & 13.75 \\
\hline \multicolumn{2}{|c|}{ LSD $_{\text {at } 5 \%}$} & 0.88 & 0.08 \\
\hline \multicolumn{4}{|c|}{ Interaction } \\
\hline \multirow{4}{*}{ Without } & Without & 89.50 & 11.69 \\
\hline & GA3 & 93.57 & 12.43 \\
\hline & HA & 94.67 & 12.72 \\
\hline & CK & 91.53 & 12.29 \\
\hline \multirow{4}{*}{$50 \%$} & Without & 90.17 & 11.93 \\
\hline & GA3 & 99.77 & 13.72 \\
\hline & HA & 101.63 & 13.97 \\
\hline & CK & 98.40 & 13.46 \\
\hline \multirow{4}{*}{$75 \%$} & Without & 96.07 & 12.87 \\
\hline & GA3 & 109.50 & 15.27 \\
\hline & HA & 111.43 & 15.47 \\
\hline & CK & 108.33 & 15.02 \\
\hline \multirow{4}{*}{$100 \%$} & Without & 97.53 & 13.17 \\
\hline & GA3 & 104.67 & 14.54 \\
\hline & HA & 106.23 & 14.74 \\
\hline & CK & 103.27 & 14.24 \\
\hline \multicolumn{2}{|c|}{ LSD $_{\text {at } 5 \%}$} & 1.76 & 0.16 \\
\hline
\end{tabular}


TABLE 3. Effect of different phosphorus levels and foliar application (gibberellin, humic acid and cyitokinen) on number of flowers/plant, number of pods/plant, as well as calculated percentage of fruit setting for faba bean

\begin{tabular}{|c|c|c|c|c|}
\hline \multicolumn{2}{|c|}{ Treatments } & No. of flowers & No. of Pods & Fruit setting \% \\
\hline \multicolumn{5}{|c|}{ P fertilization } \\
\hline \multicolumn{2}{|c|}{ without } & 10.92 & 6.92 & 63.26 \\
\hline \multicolumn{2}{|c|}{$50 \%$} & 13.25 & 9.50 & 71.21 \\
\hline \multicolumn{2}{|c|}{$75 \%$} & 16.17 & 12.83 & 78.57 \\
\hline \multicolumn{2}{|c|}{$100 \%$} & 14.67 & 11.17 & 75.97 \\
\hline \multicolumn{2}{|c|}{ LSD $_{\text {at } 5 \%}$} & 0.91 & 0.37 & 5.22 \\
\hline \multicolumn{5}{|c|}{ Growth Regulator } \\
\hline \multicolumn{2}{|c|}{ Without } & 11.42 & 7.42 & 64.57 \\
\hline \multicolumn{2}{|c|}{ GA3 } & 14.50 & 11.00 & 75.17 \\
\hline \multicolumn{2}{|c|}{ HA } & 15.08 & 11.58 & 75.87 \\
\hline \multicolumn{2}{|c|}{ CK } & 14.00 & 10.42 & 73.40 \\
\hline \multicolumn{2}{|c|}{ LSD $_{\text {at } 5 \%}$} & 0.76 & 0.71 & 5.37 \\
\hline \multicolumn{5}{|c|}{ Interaction } \\
\hline \multirow{4}{*}{ Without } & Without & 9.67 & 5.67 & 58.25 \\
\hline & GA3 & 11.33 & 7.33 & 65.55 \\
\hline & HA & 12.00 & 8.00 & 66.51 \\
\hline & $\mathbf{C K}$ & 10.67 & 6.67 & 62.73 \\
\hline \multirow{4}{*}{$50 \%$} & Without & 10.33 & 6.33 & 62.22 \\
\hline & GA3 & 14.33 & 10.67 & 74.44 \\
\hline & HA & 14.67 & 11.00 & 74.92 \\
\hline & $\mathbf{C K}$ & 13.67 & 10.00 & 73.26 \\
\hline \multirow{4}{*}{$75 \%$} & Without & 12.33 & 8.33 & 67.83 \\
\hline & GA3 & 17.33 & 14.33 & 82.68 \\
\hline & HA & 18.00 & 15.00 & 83.30 \\
\hline & CK & 17.00 & 13.67 & 80.46 \\
\hline \multirow{4}{*}{$100 \%$} & Without & 13.33 & 9.33 & 69.96 \\
\hline & GA3 & 15.00 & 11.67 & 78.01 \\
\hline & HA & 15.67 & 12.33 & 78.75 \\
\hline & CK & 14.67 & 11.33 & 77.14 \\
\hline \multicolumn{2}{|c|}{ LSD $_{\text {at } 5 \%}$} & 1.52 & 1.42 & n.s \\
\hline
\end{tabular}

It is evident from the data that spraying faba bean plants with all tested substances had significant increase on data flower expressed as number of flower, number of pods per plant as well as fruit setting over control as compared to untreated plants, the most favorable treatment in this respect was humic acid. The increment in data may be due to that humic acid stimulate plant growth by the assimilation of major and minor elements, enzyme activation and/or inhibition, 
changes in membrance permeability, protein synthesis and finally the activation of biomass production (Ulukan, 2008).

Presented data indicated that such interaction treatments had a promotive effect on data flower of faba bean plants, the interaction treatment between P-fertilization plus foliar application of humic acid resulted in the maximum values of above mentioned parameters followed by foliar spray with gibberellin then cytokinen under all levels of P-fertilization. The highest level of mentioned parameters was recorded with using $75 \%$ P-fertilization with using humic acid.

\section{Yield and its components}

Results in Table 4 showed the seed index, weight of pods and total yield as influenced by P-fertilization rates, foliar spray of different growth parameters and their interactions.

Data in Table 4 showed that; soil addition of P-rates under study significantly increased yield and its components. The highest average values of seed index, weight of pods and total yield recorded with using 75\% from recommended dose P-fertilizers.

Availability of phosphate ions causes plant's resistance to lodging, early maturity of product, higher quality, increase of plant growth from emergence to the beginning of flowering and pollination and consequently the crop yield will increase (Hosseinzadeh, 2005).

Results revealed that adding different growth regulators caused an increase in seed index, weight of pods and total yield compared to control treatment, and this increase was significant. It can be arrange these materials from which its effect as follows: Humic acid > gibberellin > cytokinen comparing with control.

This could be explained that humic acid is rich in both organic and mineral substances which are essential to plant growth and consequently increasing yield quality and quantity. Many investigators , e.g., El-Bassiony et al. (2010), Vijayakumari et al. (2012) and Shafeek et al., (2013) illustrated that high rates of humic acid on broad bean recorded the high values of total yield and its components (seed index, weight of pods and total yield).
Concerning the effect of the combination between the soil application of phosphorus and plant growth regulator on yield and its components of faba bean plant; data in the same Table indicated that there were a significant effects and the highest values of seed index, weight of pods and total yield (65.93, $44.86 \& 1347.33$, respectively) were recorded with the plants treated with $75 \% \mathrm{RD}$ and humic acide.

\section{Chlorophyll}

Regarding the effect of soil application of $\mathrm{P}$, data in Table 5 revealed that soil application of $\mathrm{P}$ significantly increased the mean values of chlorophyll (a, b \& a $+\mathrm{b} \mathrm{mg} \mathrm{g}^{-1}$ ) $\mathrm{mg} 100 \mathrm{~g}^{-1} \mathrm{~F}$.W in faba bean plants as compared with the untreated plants. On other words; the highest values recorded (0.682, 0.492 and 1.174 for chlorophyll ( $\mathrm{a}, \mathrm{b}$, total chlorophyll), respectively were realized for the $75 \%$ P-application from the recommended dose. Nyoki and Ndakidemi, (2014) on effect of P on cowpea, the results show that supplementation of phosphorus at all levels significantly increased the chlorophyll content of cowpea measured at 5 and 7 WAP compared with the control.

As shown in Table 5 , it could be observed that; a stimulation effect was happened on the mean values of the previously mentioned traits due to an application of the studied forms of plant growth regulators as humic acid, gibberellin and cytokinen. Such effect was more pronounced for the plants sprayed with humic acid, which recorded the highest values; $0.666,0.478, \& 1.145$ $\left(\mathrm{mg} . \mathrm{g}^{-1}\right)$ for chlorophyll (a, b \& a $\mathrm{b}$ ), respectively. As recorded by Farouk et al., (2011) reported that the application of HA enhanced the chlorophyll concentration in radish plant.

The different comparison between the mean values of chlorophyll $(a, b \& a+b) \mathrm{mg}^{-1}$ as affected by the combination soil application of $\mathrm{P}$ and plant growth regulators under investigation are presented in Table 5. Data clearly showed that; soil application of $\mathrm{P}$ with all sprayed plant regulators has been recorded a stimulation effect on the average values of all the aforementioned traits. In addition, the highest mean values $(0.713$, 0.516 and 1.229) were recorded for the treatment of $75 \% \mathrm{RD}$ of $\mathrm{P}$ fertilization with sprayed humic acid, while the lowest one $(0.578,0.404$, and 0.982 ) were connected with the treatment of the untreated plants. 
TABLE 4. Effect of different phosphorus levels and foliar application (gibberellin, humic acid and cyitokinen) on seed index, weight of pods and total yield of faba bean

\begin{tabular}{|c|c|c|c|c|}
\hline \multicolumn{2}{|c|}{ Treatments } & Seed index (g) & Weight of pods (g/plant) & Total yield (kg/fed) \\
\hline \multicolumn{5}{|c|}{ P fertilization } \\
\hline \multicolumn{2}{|c|}{ without } & 57.33 & 34.89 & 1054.39 \\
\hline \multicolumn{2}{|c|}{$50 \%$} & 59.99 & 37.91 & 1144.70 \\
\hline \multicolumn{2}{|c|}{$75 \%$} & 63.80 & 42.17 & 1275.88 \\
\hline \multicolumn{2}{|c|}{$100 \%$} & 62.28 & 40.61 & 1234.88 \\
\hline \multicolumn{2}{|c|}{$\mathbf{L S D}_{\text {at } 5 \%}$} & 0.17 & 0.26 & 13.42 \\
\hline \multicolumn{5}{|c|}{ Growth Regulator } \\
\hline \multicolumn{2}{|c|}{ Without } & 57.72 & 35.40 & 1070.28 \\
\hline \multicolumn{2}{|c|}{ GA3 } & 61.98 & 40.09 & 1212.37 \\
\hline \multicolumn{2}{|c|}{ HA } & 62.59 & 40.83 & 1237.05 \\
\hline \multicolumn{2}{|c|}{ CK } & 61.11 & 39.25 & 1190.15 \\
\hline \multicolumn{2}{|c|}{ LSD $_{\text {at } 5 \%}$} & 0.12 & 0.10 & 11.49 \\
\hline \multicolumn{5}{|c|}{ Interaction } \\
\hline \multirow{4}{*}{ Without } & Without & 55.42 & 33.11 & 1022.60 \\
\hline & GA3 & 57.96 & 35.53 & 1067.23 \\
\hline & HA & 58.86 & 36.11 & 1087.80 \\
\hline & CK & 57.09 & 34.80 & 1039.93 \\
\hline \multirow{4}{*}{$50 \%$} & Without & 56.28 & 33.94 & 1015.50 \\
\hline & GA3 & 61.25 & 39.23 & 1183.87 \\
\hline & HA & 61.74 & 40.10 & 1220.30 \\
\hline & CK & 60.69 & 38.35 & 1159.13 \\
\hline \multirow{4}{*}{$75 \%$} & Without & 59.36 & 36.90 & 1109.23 \\
\hline & GA3 & 65.63 & 43.93 & 1329.70 \\
\hline & HA & 65.93 & 44.86 & 1347.33 \\
\hline & CK & 64.29 & 42.99 & 1317.23 \\
\hline \multirow{4}{*}{$100 \%$} & Without & 59.83 & 37.64 & 1133.80 \\
\hline & GA3 & 63.06 & 41.67 & 1268.67 \\
\hline & HA & 63.85 & 42.27 & 1292.77 \\
\hline & CK & 62.38 & 40.87 & 1244.30 \\
\hline \multicolumn{2}{|l|}{$\mathbf{L S D}_{\text {at } 5 \%}$} & 0.24 & 0.19 & 22.98 \\
\hline
\end{tabular}


TABLE 5. Effect of different phosphorus levels and foliar application (gibberellin, humic acid and cyitokinen) on chlorophyll (a, b \& $a+b$ mg g $^{-1}$ ) for faba bean.

\begin{tabular}{|c|c|c|c|c|}
\hline \multicolumn{2}{|c|}{ Treatments } & Chlor. a, mg/g F.W & Chlor. b, mg/g F.W & Total chlo mg/g \\
\hline \multicolumn{5}{|c|}{$P$ fertilization } \\
\hline \multicolumn{2}{|c|}{ without } & 0.598 & 0.421 & 1.020 \\
\hline \multicolumn{2}{|c|}{$50 \%$} & 0.630 & 0.452 & 1.083 \\
\hline \multicolumn{2}{|c|}{$75 \%$} & 0.682 & 0.492 & 1.174 \\
\hline \multicolumn{2}{|c|}{$100 \%$} & 0.663 & 0.476 & 1.139 \\
\hline \multicolumn{2}{|c|}{ LSD $_{\text {at } 5 \%}$} & 0.005 & 0.005 & $\mathbf{0 . 0 0 7}$ \\
\hline \multicolumn{5}{|c|}{ Growth Regulator } \\
\hline \multicolumn{2}{|c|}{ Without } & 0.605 & 0.428 & 1.033 \\
\hline \multicolumn{2}{|c|}{ GA3 } & 0.658 & 0.472 & 1.130 \\
\hline \multicolumn{2}{|c|}{ HA } & 0.666 & 0.478 & 1.145 \\
\hline \multicolumn{2}{|c|}{ CK } & 0.645 & 0.464 & 1.109 \\
\hline \multicolumn{2}{|c|}{ LSD $_{\text {at } 5 \%}$} & 0.005 & 0.003 & 0.006 \\
\hline \multicolumn{5}{|c|}{ Interaction } \\
\hline \multirow{4}{*}{ Without } & Without & 0.578 & 0.404 & 0.982 \\
\hline & GA3 & 0.605 & 0.428 & 1.033 \\
\hline & HA & 0.614 & 0.433 & 1.047 \\
\hline & CK & 0.596 & 0.421 & 1.016 \\
\hline \multirow{4}{*}{$50 \%$} & Without & 0.589 & 0.413 & 1.002 \\
\hline & GA3 & 0.644 & 0.466 & 1.110 \\
\hline & HA & 0.654 & 0.474 & 1.128 \\
\hline & CK & 0.633 & 0.457 & 1.090 \\
\hline \multirow{4}{*}{$75 \%$} & Without & 0.622 & 0.442 & 1.065 \\
\hline & GA3 & 0.703 & 0.508 & 1.211 \\
\hline & HA & 0.713 & 0.516 & 1.229 \\
\hline & CK & 0.692 & 0.501 & 1.192 \\
\hline \multirow{4}{*}{$100 \%$} & Without & 0.630 & 0.451 & 1.081 \\
\hline & GA3 & 0.679 & 0.485 & 1.164 \\
\hline & HA & 0.684 & 0.490 & 1.174 \\
\hline & CK & 0.659 & 0.478 & 1.137 \\
\hline \multicolumn{2}{|c|}{ LSD $_{\text {at } 5 \%}$} & 0.009 & 0.006 & 0.011 \\
\hline
\end{tabular}

\section{$N, P, K$ in leaves and Pods}

The different comparisons tabulated in Table 6 indicated that; the average values of all nutritional elements in faba bean plant were significantly increased as a result of treating plants with the $\mathrm{P}$ fertilization investigated. The highest mean values for the previously mentioned traits were found to be associated with the addition of $75 \% \mathrm{RD}$ for $\mathrm{N}$, $\mathrm{P}$ and $\mathrm{K}$ contents. The decrease of the effects of $\mathrm{P}$ fertilization on faba bean of $\mathrm{N}, \mathrm{P}$ and $\mathrm{K}$ content

Egypt. J. Soil Sci., Vol. 57, No.1 (2017) 
started at concentrations above $75 \%$ RD causing decrease in all the measured parameters.

As for the increase in $\mathrm{N}, \mathrm{P}, \mathrm{K}$ as a result of increasing the levels of P-fertilization the role played by phosphorus for improving the growth of root system and, consequently might be due to that phosphorus might have improved and developed good root system of plant and the capacity of root to absorb more $\mathrm{N}, \mathrm{P}$ and $\mathrm{K}$ accordingly their contents increased by phosphorus applications for the soil. Optained results are confirmed with those reported by Ahmed and El-Abagy (2007) who illustrated clearly that supplied faba bean plants with P-fertilization incresed the mean values of $\mathrm{N}$ $\%$, protein $\%, \mathrm{P} \%$ and $\mathrm{K} \%$.

According to the data illustrated in the same

TABLE 6. Effect of different phosphorus levels and foliar application (gibberellin, humic acid and cyitokinen) on $(\mathrm{N}, \mathrm{P}$ and $\mathrm{K})$ in leaves and pods for faba bean

\begin{tabular}{|c|c|c|c|c|c|c|c|}
\hline & & & Leave & & & Pods & \\
\hline \multicolumn{2}{|c|}{ Treatments } & $\mathbf{N} \%$ & $\mathbf{P} \%$ & K \% & $\mathbf{N} \%$ & P \% & K\% \\
\hline \multicolumn{8}{|c|}{$P$ fertilization } \\
\hline \multicolumn{2}{|c|}{ without } & 2.81 & 0.331 & 1.86 & 2.31 & 0.271 & 1.91 \\
\hline \multicolumn{2}{|c|}{$50 \%$} & 3.06 & 0.361 & 2.16 & 2.48 & 0.304 & 2.20 \\
\hline \multicolumn{2}{|c|}{$75 \%$} & 3.42 & 0.400 & 2.59 & 2.71 & 0.348 & 2.59 \\
\hline \multicolumn{2}{|c|}{$100 \%$} & 3.28 & 0.452 & 2.43 & 2.63 & 0.332 & 2.47 \\
\hline \multicolumn{2}{|c|}{ LSD $_{\text {at } 5 \%}$} & $\mathbf{0 . 0 3}$ & 0.002 & $\mathbf{0 . 0 3}$ & 0.02 & 0.004 & $\mathbf{0 . 0 3}$ \\
\hline \multicolumn{8}{|c|}{ Growth Regulator } \\
\hline \multicolumn{2}{|c|}{ Without } & 2.85 & 0.371 & 1.93 & 2.34 & 0.277 & 1.98 \\
\hline \multicolumn{2}{|c|}{ GA3 } & 3.24 & 0.389 & 2.37 & 2.60 & 0.326 & 2.39 \\
\hline \multicolumn{2}{|c|}{ HA } & 3.30 & 0.404 & 2.44 & 2.64 & 0.334 & 2.47 \\
\hline \multicolumn{2}{|c|}{ CK } & 3.19 & 0.380 & 2.30 & 2.56 & 0.318 & 2.34 \\
\hline \multicolumn{2}{|c|}{ LSD $_{\text {at } 5 \%}$} & $\mathbf{0 . 0 3}$ & 0.005 & $\mathbf{0 . 0 3}$ & 0.01 & 0.003 & $\mathbf{0 . 0 3}$ \\
\hline \multicolumn{8}{|c|}{ Interaction } \\
\hline \multirow{4}{*}{ Without } & Without & 2.66 & 0.317 & 1.70 & 2.18 & 0.251 & 1.80 \\
\hline & GA3 & 2.84 & 0.327 & 1.92 & 2.35 & 0.279 & 1.93 \\
\hline & HA & 2.94 & 0.354 & 1.99 & 2.39 & 0.285 & 2.01 \\
\hline & CK & 2.82 & 0.325 & 1.84 & 2.32 & 0.269 & 1.89 \\
\hline \multirow{4}{*}{$50 \%$} & Without & 2.74 & 0.350 & 1.77 & 2.26 & 0.263 & 1.82 \\
\hline & GA3 & 3.18 & 0.366 & 2.28 & 2.56 & 0.316 & 2.35 \\
\hline & HA & 3.20 & 0.374 & 2.36 & 2.60 & 0.325 & 2.39 \\
\hline & CK & 3.10 & 0.354 & 2.22 & 2.51 & 0.309 & 2.25 \\
\hline \multirow{4}{*}{$75 \%$} & Without & 2.95 & 0.384 & 2.07 & 2.43 & 0.292 & 2.08 \\
\hline & GA3 & 3.57 & 0.404 & 2.77 & 2.80 & 0.366 & 2.76 \\
\hline & HA & 3.65 & 0.418 & 2.81 & 2.84 & 0.377 & 2.84 \\
\hline & CK & 3.52 & 0.395 & 2.69 & 2.76 & 0.357 & 2.69 \\
\hline \multirow{4}{*}{$100 \%$} & Without & 3.04 & 0.433 & 2.16 & 2.48 & 0.300 & 2.21 \\
\hline & GA3 & 3.37 & 0.459 & 2.51 & 2.69 & 0.342 & 2.54 \\
\hline & HA & 3.40 & 0.468 & 2.60 & 2.72 & 0.349 & 2.63 \\
\hline & CK & 3.32 & 0.447 & 2.45 & 2.65 & 0.336 & 2.52 \\
\hline \multicolumn{2}{|c|}{ LSD $_{\text {at } 5 \%}$} & 0.05 & 0.010 & 0.05 & 0.03 & 0.006 & 0.06 \\
\hline
\end{tabular}


table, it is evident that sprayed of plant growth regulators was significantly the mean values of the nutritional elements in faba bean with all forms. The increase was with using humic acid which recorded the highest mean values of $\mathrm{N}, \mathrm{P}$ and $\mathrm{K}$ content $(3.30,0.404$ and $2.44 \%$ in leaves) and (2.64, 0.334 and $2.47 \%$ in pods), respectively comparing with control treatments.

The simulative effect of humic acid on macronutrients concentrations might be explained by David et al. (1994) who indicated that humic acid enhanced cell permeability which in turn made more rapid entry of minerals into root cells and thus resulted in higher uptake of plant nutrients.

In addition, the obtained results with humic acid foliar nutrition agree with those of ElGhamry et al. (2009) on broad bean, El-Bassiony et al. (2010) on snap bean and Khan et al. (2012) on peas.

Nutritional elements concentrations in faba bean leaves and pods as affected by the interaction between all treatments under study are tabulated in Table 6 . Data revealed that, N, P and $\mathrm{K}$ content significantly affected; the mean values of the nutritional elements in faba bean tended to increase over the control treatment as a result of the interaction between the studied treatments. In this respect; the most suitable treatment which realized the highest values $(3.65,0.418,2.81$ in leaves and 2.84, 0.377 and 2.84 in pods for $\mathrm{N}, \mathrm{P}$ and $\mathrm{K} \%$ ) were connected with $75 \% \mathrm{RD}$ od $\mathrm{p}$-fertilization with sprayed plants with humic acid.

\section{Quality}

Data presented in Table 7 showed the average values of Protein, total carbohydrates, fiber and ash $\%$ for faba bean plant as affected by the interaction between applied of phosphorus fertilization and growth regulator as foliar application of gibberellin, humic acid and cyitokinen.

It can be observed that; soil application of phosphorus at the rate of 75 from recommended doses significantly increased the mean values of the aforementioned traits than those obtained for the untreated plants. Application of phosphorus chemical fertilizers separately significant increased ash content, protein and carbohydrates of faba bean seeds, as observed by Rugheim and Abdelgani (2009).
Within the growth regulator; data of the same table revealed a superiority effect for humic acid followed by gibberellin and lastly cyitokinen. The mean values of protein, total carbohydrates, fiber and ash \% were 16.48, 54.46, 11.23 and 4.57, respectively. El-Hefny, (2010) claimed that humic acid application up to $6 \mathrm{~kg} /$ fed increased the highest $\mathrm{N}, \mathrm{P}$ and $\mathrm{K}$ uptake and increased $\mathrm{K} / \mathrm{Na}$, $\mathrm{Ca} / \mathrm{Na}$ ratio, protein and carbohydrates contents of cowpea plants.

Moreover, increasing the level of phosphorus significantly increased the mean values of the aforementioned traits less than those obtained for the control treatment until $75 \% \mathrm{RD}$. under any form of regulator growth. Thus, it can be observed that the most suitable treatment, which realized the highest mean values of Protein, total carbohydrates, fiber and ash \% of faba bean plant was connected with the plants treated with $75 \%$ from recommended dose of phosphorus fertilization and humic acid.

\section{Available N, $P$ and $K$}

Statistical analysis of the data presented in Table 8 indicated that, all treatments under investigation were significantly affected the average values of available $\mathrm{N}, \mathrm{P}$ and $\mathrm{K}$ ppm in the soil after planting faba bean plant.

It is evident that; the highest mean values of available $\mathrm{N}, \mathrm{P}$ and $\mathrm{K}$ ppm in the soil were recorded for the plants treated with P-fertilization at the rate of $75 \%$ from recommended dose, while the lowest values of such traits were realized for the untreated plants.

Referring the effect of plant growth regulators data in the same table showed that; the average values of available $\mathrm{N}, \mathrm{P}$ and $\mathrm{K}$ ppm in the soil were significantly increased under any forms. Generally, the most suitable treatment which realized the highest values of available N, P and $\mathrm{K}$ ppm in the soil was associated with the plants treated with humic acid as foliar addition. Salama, (2011) resulted that, the highest absorption for $\mathrm{N}$ and $\mathrm{P}$ from the soil by the roots of faba bean and sorghum plants was connected with the treatments of humic acid. Such effect did not reach to the level of significance between the mean values of $\mathrm{K} \mathrm{mg.} \mathrm{kg}^{-1}$ in the soil after cultivating of faba bean and sorghum plants.

As for the interaction effect of levels of 
phosphorus and different sources of plant growth regulators on available $\mathrm{N}, \mathrm{P}$ and $\mathrm{K}$ ppm in the soil after planting faba bean, data in the same table indicated that the highest values of aforementioned parameters realized under using humic acid as foliar application and $75 \%$ of phosphorus from recommended dose.

TABLE 7. Effect of different phosphorus levels and foliar application (gibberellin, humic acid and cyitokinen) on C. Protein \%, T. carbohydrates \% , Crude fiber \%and Ash \% for plant

\begin{tabular}{|c|c|c|c|c|c|}
\hline & Treatments & $\begin{array}{c}\text { C. } \\
\text { Protein \% } \\
\text { (Pods) }\end{array}$ & $\begin{array}{c}\text { T. } \\
\text { carbohydrates } \\
\text { \% (Pods) }\end{array}$ & $\begin{array}{c}\text { Crude } \\
\text { fiber } \%\end{array}$ & $\begin{array}{c}\text { Ash } \\
\%\end{array}$ \\
\hline \multicolumn{6}{|c|}{$P$ fertilization } \\
\hline \multicolumn{2}{|r|}{ Without } & 14.42 & 52.54 & 12.72 & 3.97 \\
\hline \multicolumn{2}{|r|}{$50 \%$} & 15.51 & 53.47 & 11.93 & 4.31 \\
\hline \multicolumn{2}{|r|}{$75 \%$} & 16.92 & 54.89 & 10.89 & 4.62 \\
\hline \multicolumn{2}{|r|}{$100 \%$} & 16.48 & 54.36 & 11.28 & 4.51 \\
\hline \multicolumn{2}{|r|}{ LSD $_{\text {at } 5 \%}$} & 0.09 & 0.13 & 0.04 & 0.14 \\
\hline \multicolumn{6}{|c|}{ Growth Regulator } \\
\hline \multicolumn{2}{|r|}{ Without } & 14.59 & 52.69 & 12.55 & 3.98 \\
\hline \multicolumn{2}{|r|}{ GA3 } & 16.27 & 54.17 & 11.43 & 4.43 \\
\hline \multicolumn{2}{|r|}{ HA } & 16.48 & 54.46 & 11.23 & 4.57 \\
\hline \multicolumn{2}{|r|}{ CK } & 16.00 & 53.93 & 11.60 & 4.43 \\
\hline \multicolumn{2}{|r|}{$\mathbf{L S D}_{\text {at } 5 \%}$} & 0.09 & 0.07 & 0.05 & 0.10 \\
\hline \multicolumn{6}{|c|}{ Interaction } \\
\hline \multirow{4}{*}{ Without } & Without & 13.63 & 51.95 & 13.15 & 3.74 \\
\hline & GA3 & 14.69 & 52.73 & 12.62 & 3.99 \\
\hline & HA & 14.90 & 52.98 & 12.35 & 4.09 \\
\hline & CK & 14.47 & 52.51 & 12.76 & 4.04 \\
\hline \multirow{4}{*}{$50 \%$} & Without & 14.11 & 52.26 & 12.93 & 3.86 \\
\hline & GA3 & 15.99 & 53.84 & 11.60 & 4.31 \\
\hline & HA & 16.27 & 54.14 & 11.41 & 4.62 \\
\hline & CK & 15.70 & 53.63 & 11.77 & 4.47 \\
\hline \multirow{4}{*}{$75 \%$} & Without & 15.17 & 53.19 & 12.18 & 4.12 \\
\hline & GA3 & 17.52 & 55.47 & 10.45 & 4.82 \\
\hline & HA & 17.74 & 55.73 & 10.30 & 4.86 \\
\hline & CK & 17.27 & 55.16 & 10.62 & 4.68 \\
\hline \multirow{4}{*}{$100 \%$} & Without & 15.48 & 53.38 & 11.95 & 4.21 \\
\hline & GA3 & 16.88 & 54.66 & 11.04 & 4.61 \\
\hline & HA & 17.00 & 54.97 & 10.86 & 4.72 \\
\hline & CK & 16.55 & 54.42 & 11.26 & 4.51 \\
\hline \multicolumn{2}{|r|}{$\mathbf{L S D}_{\text {at } 5 \%}$} & 0.18 & 0.14 & 0.11 & 0.21 \\
\hline
\end{tabular}


TABLE 8. Effect of different phosphorus levels and foliar application (gibberellin, humic acid and cyitokinen) on Available (N, P and $K$ ) in soil

\begin{tabular}{|c|c|c|c|c|}
\hline \multicolumn{2}{|c|}{ Treatments } & Available N (ppm) & Available $P(p p m)$ & $\begin{array}{l}\text { Available K } \\
\text { (ppm) }\end{array}$ \\
\hline \multicolumn{5}{|c|}{ P fertilization } \\
\hline \multicolumn{2}{|c|}{ without } & 59.10 & 7.83 & 248.30 \\
\hline \multicolumn{2}{|c|}{$50 \%$} & 68.55 & 9.93 & 289.38 \\
\hline \multicolumn{2}{|c|}{$75 \%$} & 81.45 & 12.39 & 342.43 \\
\hline \multicolumn{2}{|c|}{$100 \%$} & 77.30 & 11.71 & 322.95 \\
\hline \multicolumn{2}{|c|}{ LSD $_{\text {at } 5 \%}$} & 0.02 & 0.01 & 0.11 \\
\hline \multicolumn{5}{|c|}{ Growth Regulator } \\
\hline \multicolumn{2}{|c|}{ Without } & 61.03 & 8.21 & 255.58 \\
\hline \multicolumn{2}{|c|}{ GA3 } & 74.95 & 11.21 & 316.08 \\
\hline \multicolumn{2}{|c|}{ HA } & 77.48 & 11.68 & 325.80 \\
\hline \multicolumn{2}{|c|}{ CK } & 72.95 & 10.75 & 305.60 \\
\hline \multicolumn{2}{|c|}{ LSD $_{\text {at } 5 \%}$} & 0.04 & 0.01 & 0.16 \\
\hline \multicolumn{5}{|c|}{ Interaction } \\
\hline \multirow{4}{*}{ Without } & Without & 53.90 & 6.09 & 227.40 \\
\hline & GA3 & 60.70 & 8.39 & 255.20 \\
\hline & HA & 63.50 & 8.92 & 264.70 \\
\hline & CK & 58.30 & 7.90 & 245.90 \\
\hline \multirow{4}{*}{$50 \%$} & Without & 55.80 & 7.41 & 236.50 \\
\hline & GA3 & 72.60 & 10.75 & 307.50 \\
\hline & HA & 75.40 & 11.26 & 317.40 \\
\hline & CK & 70.40 & 10.28 & 296.10 \\
\hline \multirow{4}{*}{$75 \%$} & Without & 65.90 & 9.45 & 273.80 \\
\hline & GA3 & 86.50 & 13.35 & 365.70 \\
\hline & HA & 88.10 & 13.70 & 376.30 \\
\hline & CK & 85.30 & 13.04 & 353.90 \\
\hline \multirow{4}{*}{$100 \%$} & Without & 68.50 & 9.89 & 284.60 \\
\hline & GA3 & 80.00 & 12.33 & 335.90 \\
\hline & HA & 82.90 & 12.84 & 344.80 \\
\hline & CK & 77.80 & 11.79 & 326.50 \\
\hline \multicolumn{2}{|c|}{$\mathbf{L S D}_{\text {at } 5 \%}$} & 0.07 & 0.01 & 0.32 \\
\hline
\end{tabular}

\section{Conclusions}

Under the same condition of this investigation it can be concluded that; soil addition of $75 \%$ Egypt. J. Soil Sci., Vol. 57, No.1 (2017) from recommended dose P-fertilizers, presence of Humic acid applied in foliar way is considered to be the most suitable treatment for realizing the highest safe yield quality of faba bean plant. 


\section{References}

Abdalsalam, A. A. and Al-Shebani, Y. A. (2010) Effect of various nitrogen and phosphorus fertilization levels on growth, yield and yield attributes of local mungbean (Vigna radiata L.) R. Wilczek) in Yemen. Egypt. J. of Appl. Sci., 25 (2A), 57-71.

Afifi, M. H. M.; Mohamed, M. F. and Shaaban, H. A. (2010) Yield and nutrient uptake of some faba bean varieties grown in newly cultivated soil as affected by foliar application of humic acid. J. of Plant Production, 1 (1), 77-85.

Agrilasa (2002) Handbook on feeds and plant analyses. AGRILASA, Pretoria. South Africa.

Ahmed, M. A. and El-Abagy,H. M. H. (2007) Effect of bio-and mineral phosphorus fertilizer on growth, productivity and nutritional value of some faba bean (Vicia Faba L.) cultivars in Newly cultivated land. J. of Applied Sci. Res., 3 (6) 408-420.

AOAC (2006). Official Methods of Analysis, Ascorbic Acid in Vitamin Preparation and Juices. 2, 6Dichloroindophenol Titrimetric Method. Vitamins and Other Nutrients Chapter 45, p. 19.

Cazzato, E., Tufarelli, V., Ceci, E., Stellacci, A.M. andLaudadio, V. (2012) Quality, yield and nitrogen fixation of faba bean seeds as affected by sulphur fertilization. Acta Agriculturae Scandinavica Section B: Soil and Plant Science, 62, 732-738.

David, P. P.; Nelson, P. V. and Sanders,D. C. (1994) A humic acid improves growth of tomato seedlings in solution culture. J. Plant Nutr., 17, 173-184.

El-Bassiony, A. M.; Fawzy, Z. F., Abd El-Baky,M. M. H. and Mahmoud, A. R. (2010) Response of snap bean plants to mineral fertilizers and humic acid application. Res. J. Agric. \& Biol. Sci., 6 (2) 169-175.

El-Ghamry, A. M.,Abd El-Hai, K. M. and Ghoneem, K. M. (2009) Amino and humic acids promote growth, yield and disease resistance of faba bean cultivated in clayey soil. Aust. J. Basic \& Appl. Sci., 3 (2) 731739.

El-Habbasha, S.F., Hozayn, M. and Khalafallah, M.A. (2007) Integration effect between phosphorus levels and bio-fertilizers on quality and quantity yield of faba bean (Vicia faba, L) in newly cultivated sandy soils. Res. J. of Agric. \& Bio. Sci., 3 (6) 966-971.

El-Hefny, E. M. (2010) Effect of saline irrigation water and humic acid application on growth and productivity of two cultivars of cowpea (Vigna unguiculata L. Walp.). Australian Journal of Basic and Applied Sciences, 4, 6154-6168.

FAO-IFA. (2000) Fertilizers and Their Use. $4^{\text {th }}$ edition, FAO, Rome.

Farouk, S.; Mosa, A. A., Taha, A. A.,Ibrahim,H. M. and El-Gahmery, A. M. (2011) Protective effect of humic acid and chitosan on radish (Raphanus sativus, L. var. sativus) plants subjected to cadmium stress. J. Stress Physiol. Biochem., 7 (2) 99-116.

Gavrilenko V. F. and Zigalova, T. V. (2003) The Laboratory Manual for the Photosynthesis. Academia, Moscow. 256 стр. (in Russian).

Gomez, K. A. and Gomez, A. A. (1984) Statistical Procedures for Agricultural Research, 2nd ed, John Wiley and Sons., Inc. NewYork.

Haluschak, P. (2006) Laboratory Methods of Soil Analysis. Canada-Manitoba Soil Survey. April

Hosseinzadeh, H. (2005) Report of effect Barvare 2 biofertilizer on yield grain legume. Tehran Jehad. Daneshgahi and FannavariSabz.Co.Press. p. 25.

Khan, A.; Gurmani,A., Khan,M. Z. , Hussain, F., Akhtar, M. E. and Khan,S. (2012) Effect of humic acid on the growth, yield, nutrient composition, photosynthetic pigment and total sugar contents of Peas (Pisum Sativum L). J. of the Chemical Society of Pakistan, 1, 1-7.

Maske, V.G.; Dotale, R.D.; Sorte, P.N.; Tale, B.D. and Chore, C.N. (1997) Germination, root and shoot studies in soybean as influenced by GA3 and NAA. Journal of Soils and Crops, v.7, p.147-149.

Mertens, D. (2005a) AOAC Official method 922.02. plants preparation of laboratuary sample. Official Methods of Analysis, 18th ed. North Frederick Avenue, Gaitherburg, Maryland, 1-2 pp.

Mertens, D. (2005b) AOAC Official method 975.03. Metal in plants and pet foods. Official Methods of Analysis, 18th ed. North Frederick Avenue, Gaitherburg, Maryland, 3-4 pp. 
Mesut, K. C.; Türkmen,Ö. , Turan, M. and Tuncer , B. (2010) Phosphorus and humic acid application alleviate salinity stress of pepper seedling. African Journal of Biotechnology, 9 (36) 5845-5851.

Nardi, M. R; Diego, P., Fabiano, R. and Muscolo, A. (1999) Biological activity of humic substances extracted from soils under different vegetation covar commum. Soil Sci. Plant Anal., 30 (596) 621-634.

Ndakidemi, P. A. and Dakora, F. D. (2007) Yield components of nodulated cowpea (Vigna unguiculata L.) Walp) and maize (Zea mays) plants grown with exogenous phosphorus in different cropping systems. Aust. J. Exp. Agric. 47, 587-590.

Nyoki, D. and Patrick, A. N. (2014) Effects of phosphorus and Bradyrhizobium japonicum on growth and chlorophyll content of cowpea (Vigna unguiculata L.) Walp). American Journal of Experimental Agriculture 4, 1120-1136.

Ranganna, S. (2001) Analysis and quality control for fruits and vegetable products. Tata Mc Grawhill Publication, New Delhi.

Reeuwijk, L. P. (2002) Procedures For Soil Analysis. Inter. Soil Ref. and Info. Center. Food and Agric. Organization of the United Nations.

Rugheim, A. M. and Abdelgani, M. E. (2009) Effects of microbial and chemical fertilization on yield and seed quality of faba bean. $9^{\text {th }}$ Conference of the th African Crop Science Society: - Science and Technology Supporting Food Security in Africa. Cape Town, South Africa 28 September -1 October 2009.

Sahelemedhin, S. and Taye, B. (Editors) (2000) Procedures for Soil and Plant Analysis. National Soil Res. Center, Addis Ababa, Ethiopia.

Salama, S. F. A. (2011) Effect of using some soil amendments on phosphorus mobility and phosphorus fertilizers use efficiency in calcareous soil. M. SC. Thesis, Fac. Agric. Mans. Univ. Egypt.

Samavat, S. (2007) Evaluation of humic acid in various organic materials and the effects of urban waste compost humic acid on some soil. Proceedings of the Xth Congress of Soil Science, Karaj, Iran, pp.714-716.
Shafeek, M. R.; Helmy, Y. I., Nadia, M. O. and Rizk, F. A. (2013) Effect of foliar fertilizer with nutritional compound and humic acid on growth and yield of broad bean plants under sandy soil conditions. J. of Applied Sci. Res., 9 (6) 3674-3680.

Sharaan, A.N., Ekram, A., Megawer, H.A.S. and Hemida, Z.A. (2004) Seed yield, yield components and quality character as affected bycultivars, sowing dates and planting distances in faba bean. Bull. Agric. Econ. Min. Agric. Egypt.

Singh, J. P. (1988) A rapid method for determination of nitrate in soil and plant extracts: Plant and Soil. 110, 137-139

Taiz, L. and Zeiger, E. (2010) Gibberellins: regulators of plant height. In: Zeiger, E. (Ed.), Plant Physiology. Sinauer Associates, Incorporated: Hard Cover, pp. 461-493.

Ulukan, H. (2008) Effect of soil applied humic acid at different sowing tines on some yield components in wheat (Triticum spp.) hybrids Int. J. Bot., 4 (2) 164-175.

Vijayakumari, B.; Yadav, R. H., Gowri, P. and Kandari, L. S. (2012) Effect of panchagavya, humic acid and micro herbal fertilizer on the yield and post harvest soil of soya bean (Glycine max L.). Asian J. of Plant Sci., 11 (2),83-86.

Wu, M. C. (2002) Food Analysis and Sensory Evaluation (in Chinese). China Agric. Press, Beijing.

Y. Jia and V.M. Gray (2008) Growth yield of Vicia faba L. in response to microbial symbiotic associations, S. Afric, J. Bot. $\mathbf{7 4}, 25 \mathrm{e} 32$.

(Received : $4 / 1 / 2016$ accepted : 16/3/2016) 
تأثير اضافة مستويات من الفوسفور مع بعض منظمات نمو على انتاجية الفول

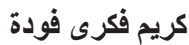

قسم الأراضى - كلية الزراعة - جامعة المنصورة - مصر.

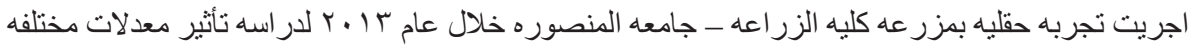

من التسميد الفوسفاتي كاضضافه ارضيك مع الرش بمصادر مختلفه من (جبرلين و هيو ميك و سيتو كينين )

اشتملت التجربه على 17 معامله فى تصميم قطاعات منشقه فـى ب مكررات تمثل التفاعلات الممكنه بين

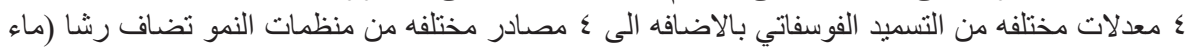

حنفيه، جبرلين و هيوميلك و سيتو كينين).

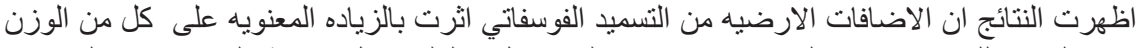

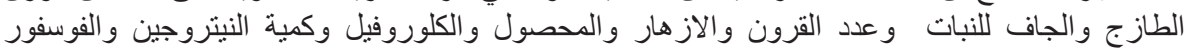

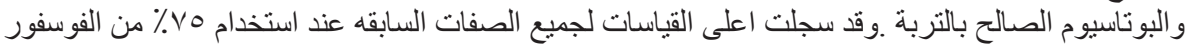

و ايضا سجلت عند استخدام الهيوميك رشا العلي قيمة يليها الجبرلين و يليهم السيتو كينين. 